\title{
Studies on the Exogenous Application of Plant Growth Regulators on Morphological and Biochemical Changes in Gladiolus (Gladiolus grandiflorus L.) Leaf
}

\author{
Priyaranjan Koley $^{1 *}$, Soumen Maitra ${ }^{2}$ and Indrajit Sarkar ${ }^{2}$ \\ ${ }^{1}$ Department of Horticulture, M. S. Swaminathan School of Agriculture, \\ Parlakhemundi, Orisha, India \\ ${ }^{2}$ Department of Floriculture, Medicinal and Aromatic Plants, Uttar Banga Krishi \\ Viswavidyalaya, Faculty of Horticulture, Pundibari, Cooch Behar, West Bengal, India \\ *Corresponding author
}

\section{A B S T R A C T}

Keywords

Gladiolus,

Gibberellic Acid,

BA, Triacontanol

Article Info

Accepted:

20 August 2019

Available Online:

10 September 2019
An experiment was conducted following Randomized Block Design at the instructional field of the Department of Floriculture, Medicinal and Aromatic Plants, Uttar Banga Krishi Viswavidyalaya, Pundibari, CoochBehar, West Bengal, India from October, 2013 to April, 2014. Three different plant growth regulators viz., Gibberellic acid $\left(\mathrm{GA}_{3}\right), \mathrm{N}^{6}$ Benzyladenine (BA) and Triacontanol each at 3 different levels (25ppm, 50ppm and $100 \mathrm{ppm}$ ) were applied on Gladiolus cv. American Beauty and the effect was compared to control (distilled water). Each treatment was replicated thrice. In the present experiment, application of $\mathrm{GA}_{3} 25 \mathrm{ppm}$ increased the initial leaf length $(10.05 \mathrm{~cm})$ and leaf chlorophyll content (62.30 SPAD value) but $\mathrm{GA}_{3} 50 \mathrm{ppm}$ increased the phenol content of leaves (1.84 $\mathrm{mg} / \mathrm{g}$ of fresh wt.), whereas, $\mathrm{GA}_{3} 100 \mathrm{ppm}$ increased the leaf protein content $(2.49 \mathrm{mg} / \mathrm{g}$ of fresh wt.). Exogenous application of BA $25 \mathrm{ppm}$ improved the reducing sugar content of leaves $(4.230 \mathrm{mg} / \mathrm{g}$ of fresh weight) while, BA $100 \mathrm{ppm}$ improved leaf enzymatic activity (1.27 $\Delta 490 \mathrm{~nm} / \mathrm{min} / \mathrm{g}$ fresh weight). Application of Triacontanol 50ppm improved initial plant height $(14.49 \mathrm{~cm})$, initial leaf production $(3.08)$, initial and final leaf width $(1.68 \mathrm{~cm}$ and $2.63 \mathrm{~cm}$ respectively), leaf enzyme activity $(1.27 \Delta 490 \mathrm{~nm} / \mathrm{min} / \mathrm{g}$ fresh weight) and final leaf length $(57.96 \mathrm{~cm})$. Triacontanol 100ppm improved final leaf production (11.61) and plant height $(75.67 \mathrm{~cm})$. Results revealed that Triacontanol 50ppm and 100ppm improved the vegetative growth of Gladiolus which is the integral activity towards improvement of the yield attributing characters and hence may be recommended for commercial cultivation of gladiolus in the Terai region of West Bengal.

\section{Introduction}

Flowers are symbols of beauty, love and peace. It is one of the stunning gifts to the mankind from the end of the nature that brings joy and happiness. They form the soul of garden and convey the message of nature to man (Havale et al., 2008). Gladiolus is one of the most popular cut flowers in the world for its majestic spikes (Sinha and Roy, 2002). Cut flower trade has become a profitable enterprise for many flower growing countries. 
Gladiolus hold fourth place as a cut flower in international market after Rose, Carnation and Chrysanthemum (Farhat, 2004). In Netherland and other European countries, it ranked second after tulip as a cut flower among the bulbous flowers (Singh, 2006). The name of Gladiolus is derived from the Latin word 'Gladius', because of its sword like leaves and therefore, it is called as 'Sword lily'. $G$. illyricus is found wild as weed in the corn field in Europe, that's why, it is named as 'Corn flag'. The leaves are attached to the stem in opposite direction, i.e., two-ranked. Fewer roots may also originate from the base of the aerial shoot (Mukhopadhyay, 2002). In West Bengal, the major Gladiolus producing districts include Darjeeling, Midnapore (East \& West), Nadia, Jalpaiguri, Howrah and North 24-Parganas (Anon., 2014). Commercial production of Gladiolus showed a gradual increase in past few years (Memon, 2009). In West Bengal, gladioli hold second position among the cut flowers and Darjeeling district shared highest area, production and productivity within the state (Anon, 2014). Plant growth regulators are organic substances with important functions in regulating growth depending on its concentration and other intrinsic characteristics of the plant (Marcos et al., 2011). They enhance the source-sink relationship or stimulate the translocation of photo-assimilates thereby influencing the plant growth, flower formation, fruit development, seed development and ultimately improve the productivity of the crops (Amanullah and Vincent, 2010). Among exogenous gibberellins, $\mathrm{GA}_{3}$ is commonly responsible to increase the height of plants, vegetative growth and internodal distance, through altering cell division, elongation and expansion (Da Silva et al., 2011; Shankar, 2011) and ultimately increase the total plant growth (Umrao et al., 2007). It also promoted the sprouting, stem elongation, increased leaf production in different floricultural crops (Rani, 2013). Exogenous application of BA improved the yield attributes in field crops seemed to be due to increased availability of assimilates which in turn might cause greater chlorophyll synthesis as observed by Reddy et al., (2009) in Cowpea. Another important plant growth regulator is Triacontanol. According to Mandava (1979), it is a secondary plant growth substance and cannot be considered as a phytohormone. Such types of growth regulators enhance the physiological efficiency of the cells. In India most of the studies involving Triacontanol are confined to natural extracts. Triacontanol improves better root development resulting effective utilization of nutrient as well as improved the photosynthetic activity in crops thus increasing enzyme activities, free amino acids, reducing sugars and soluble protein of plants (Naeem et al., 2011).

\section{Materials and Methods}

An experiment was conducted at the instructional field of the Department of Floriculture, Medicinal and Aromatic plants, Faculty of Horticulture, Uttar Banga Krishi Viswavidyalaya, Pundibari, CoochBehar, West Bengal, from October, 2013 - April, 2014 to study the effect of corm dipping as well as exogenous spraying of plant growth regulators on the morphological and biochemical changes occurred in Gladiolus leaves.

Three potent plant growth regulators namely Gibberellic Acid $\left(\mathrm{GA}_{3}\right), \mathrm{N}^{6}$ - Benzyl Adenine and Triacontanol each at three different levels $(25,50$ and 100ppm) were applied twice - as corm dipping treatment for six hours at one day prior to planting as well as spraying on standing crop of Gladiolus at three weeks after planting and the effects were compared to control (distilled water dipping and spray) plants following Randomized Block Design with 10 treatments replicated thrice. Healthy, disease-free corms of Gladiolus cv. American 
Beauty having diameter of $37.05-40.56 \mathrm{~mm}$ and $20-26 \mathrm{~g}$ in weight were selected for the experiment and treated with Carbendazim 50 WP (Bavistin) @1g/ lit of water for an hour at one week before planting. The treatment details is presented below -

$\mathrm{T}_{0}$ - Control (Distilled Water) $\mathrm{T}_{1}-\mathrm{GA}_{3} @ 25 \mathrm{ppm}$

$\mathrm{T}_{2}-\mathrm{GA}_{3} @ 50 \mathrm{ppm} \quad \mathrm{T}_{3}-\mathrm{GA}_{3} @ 100 \mathrm{ppm}$

$\mathrm{T}_{4}-\mathrm{BA} @ 25 \mathrm{ppm} \mathrm{T}_{5}-\mathrm{BA} @ 50 \mathrm{ppm}$

$\mathrm{T}_{6}$ - BA@100ppm $\mathrm{T}_{7}$ - Triacontanol @ 25pp m

$\mathrm{T}_{8}$ - Triacontanol @ 50ppm $\mathrm{T}_{9}$ - Triacontanol @ 100ppm

Treatment and replication-wise average data of plant height $(\mathrm{cm})$, number of leaves per plant, leaf length $(\mathrm{cm})$, leaf width $(\mathrm{cm})$ each at 21 and 63 days after planting, canopy temperature $\left({ }^{0} \mathrm{C}\right)$, leaf chlorophyll content (SPAD Value) using chlorophyll meter SPAD 502 at 10:00 AM on clear sunny day after 60 days of planting, reducing sugar content of leaf ( $\mathrm{mg}$ per $\mathrm{g}$ of fresh weight) following the procedures of Nelson (1944) and Somogyi (1945) at $620 \mathrm{~nm}$, non-reducing sugar content of leaf ( $\mathrm{mg}$ per $\mathrm{g}$ of fresh weight) following the procedures of Nelson (1944) and Somogyi $(1945)$ at $620 \mathrm{~nm}$, leaf protein content (mg per $\mathrm{g}$ of fresh weight) following the procedure of Lowry (1951) with Folin-Ciocaltaeu reagent and Bovine serum albumin standard curve, leaf phenol content ( $\mathrm{mg}$ per $\mathrm{g}$ of fresh weight) following the procedure of Malick and Singh (1980) with Catechol at $650 \mathrm{~nm}$ and enzyme (peroxidase) activity $(\Delta 490 \mathrm{~nm} / \mathrm{min} / \mathrm{g}$ fresh wt.) following the procedure of Sadasivam and Manickam (1996) with pyrogallol and hydrogen peroxide were collected and analyzed according to the Fisher's analysis of variance techniques using mstatC software.

\section{Results and Discussion}

The effect of plant growth regulator applications was found statistically significant in all the parameters studied except initial plant height at 21 days after planting, initial leaf width at 21 days after planting and nonreducing sugar content of Gladiolus leaves cv.
American Beauty. Corms and plants treated with 50ppm Triacontanol showed the maximum plant height $(14.49 \mathrm{~cm})$ at 21 days after planting (Table -1). Plant height was significantly increased at 63 days after planting of gladiolus when treated with Triacontanol 100ppm $(75.67 \mathrm{~cm})$ which was statistically at par with the effect of $100 \mathrm{ppm}$ $\mathrm{GA}_{3}(71.67 \mathrm{~cm})$. The minimum plant height at this stage $(51.12 \mathrm{~cm})$ was noticed with $50 \mathrm{ppm}$ BA treatment.

Application of plant growth regulators increased the leaf production of gladiolus both at 21 and 63 days after planting. Initially all the treatments performed better except BA and Triacontanol at higher level (100ppm) with values of 1.96 and 2.08 respectively. Though Triacontanol 50ppm performed better initially (3.08 leaves) but at 63 days after planting Triacontanol 100ppm treatment produced maximum number of leaves (11.61) which was at par with $\mathrm{GA}_{3}$ 100ppm (10.83 leaves). The negative effects were observed finally (table - 1) with $\mathrm{GA}_{3}$ 50ppm and Triacontanol 25ppm (6.17 leaves both).

Initially $\mathrm{GA}_{3}$ 25ppm showed highest leaf length $(10.05 \mathrm{~cm})$ which was at par with Triacontanol 50ppm $(9.24 \mathrm{~cm})$ but afterwards Triacontanol 50ppm produced the maximum leaf length $(57.96 \mathrm{~cm})$ of gladiolus at 63 DAP which was at par with $\mathrm{GA}_{3}$ 100ppm (57.72 $\mathrm{cm})$, BA 100ppm $(56.06 \mathrm{~cm})$ and Triacontanol $100 \mathrm{ppm}(52.00 \mathrm{~cm})$. The minimum leaf lengths were observed initially with BA 50ppm $(4.06 \mathrm{~cm})$ and finally with Triacontanol $25 \mathrm{ppm}$ $(39.81 \mathrm{~cm})$ treatments $($ table -1$)$.

Application of Triacontanol 50ppm significantly increased leaf width both at 21 $(1.68 \mathrm{~cm})$ and $63(2.63 \mathrm{~cm})$ days after planting. Use of BA $50 \mathrm{ppm}(0.48 \mathrm{~cm})$ and BA $100 \mathrm{ppm}$ $(1.14 \mathrm{~cm})$ proved inhibitory regarding leaf width at 21 and 63 days after planting of Gladiolus respectively. The maximum 
$\left(25.38^{\circ} \mathrm{C}\right)$ Canopy temperature (Figure - 1) was found with $\mathrm{GA}_{3} 100 \mathrm{ppm}$ treatment. Control plants showed better effect $\left(22.77^{\circ} \mathrm{C}\right)$ over some of the PGR treatments like all levels of Triacontanol and BA 50 and $100 \mathrm{ppm}$. Plants treated with $\mathrm{GA}_{3} 25 \mathrm{ppm}$ resulting the maximum leaf chlorophyll content (62.30 SPAD) in Gladiolus, which was statistically significant and on par with the effect of BA 50ppm (61.47 SPAD). All the plant growth regulator applications produced higher leaf chlorophyll content in Gladiolus (Figure - 2) over control (57.33 SPAD).

Corms and plants of Gladiolus cv. American Beauty when treated with BA 25ppm recorded maximum reducing sugar content in leaves $(4.230 \mathrm{mg} / \mathrm{g}$ of fresh weight). All the plant growth regulator treatments showed better result over control $(4.163 \mathrm{mg} / \mathrm{g}$ of fresh weight) in this aspect (Table - 2) but, control plants produced the maximum non-reducing sugar content $(0.39748 \mathrm{mg} / \mathrm{g}$ of fresh wt.) in leaves which was found statistically nonsignificant. Treatment with $\mathrm{GA}_{3}$ 100ppm generated the maximum leaf protein content (2.49 mg/g of fresh weight) which was on par with the effect of control $(2.45 \mathrm{mg} / \mathrm{g}$ of fresh weight $), \mathrm{GA}_{3} 25 \mathrm{ppm}(2.40 \mathrm{mg} / \mathrm{g}$ of fresh weight $), \mathrm{GA}_{3} 50 \mathrm{ppm}(2.34 \mathrm{mg} / \mathrm{g}$ of fresh weight) and Triacontanol 100ppm $(2.31 \mathrm{mg} / \mathrm{g}$ of fresh weight). The minimum leaf protein $(1.84 \mathrm{mg} / \mathrm{g}$ of fresh weight) was obtained from Triacontanol 25ppm treatment. Leaf phenol content was found highest with $\mathrm{GA}_{3} 50 \mathrm{ppm}$ $(1.84 \mathrm{mg} / \mathrm{g}$ of fresh weight) and lowest with $\mathrm{GA}_{3} 100 \mathrm{ppm}(0.27 \mathrm{mg} / \mathrm{g}$ of fresh weight). The effect of plant growth regulators on the enzyme activity of leaves was found statistically significant (Table -2 ). Corms and plants treated with BA 100ppm and Triacontanol 50ppm recorded maximum enzyme activity of leaves $(1.27 \Delta 490 \mathrm{~nm} / \mathrm{min} / \mathrm{g}$ fresh weight) which were at par with $\mathrm{BA}$ 50ppm, $\mathrm{GA}_{3}$ 100ppm and control (1.20 $\Delta 490 \mathrm{~nm} / \mathrm{min} / \mathrm{g}$ fresh wt.) treatments in this regard. Corms and plants treated with Triacontanol $25 \mathrm{ppm}$ showed the least effect $(1.07 \Delta 490 \mathrm{~nm} / \mathrm{min} / \mathrm{g}$ fresh weight).

Plant growth regulators often called as plant bio-regulators are the compounds which are applied exogenously to modify the plant physiological processes to produce a gainful output. Improvement of growth of gladiolus through exogenous application of $\mathrm{GA}_{3}$ can be attributed to enhance the source-sink relationship or to stimulate the translocation of photo-assimilates was also observed by Khan et al., (2013) in gladiolus. In the present experiment application of $\mathrm{GA}_{3} \quad 25 \mathrm{ppm}$ increased the initial leaf length. These observations are in conformity with the earlier reports of Sudhakar and Kumar (2012) in Gladiolus and this might be due to the growth promoting effect of $\mathrm{GA}_{3}$ in stimulating and accelerating cell division and/or cell enlargement or both, photosynthetic and metabolic activities, developing plants having taller leaves (Sajid et al., 2015). $\mathrm{GA}_{3}$ 25ppm also increased the chlorophyll content of leaf. The result is in accordance with the findings of Janowska and Jerzy (2003) that higher chlorophyll content $\left(100 \mathrm{mg} \mathrm{L}^{-1}\right)$ clearly indicating the dominating effect of $\mathrm{GA}_{3}$. The result might be due to the ability of gibberellic acid to prevent the degradation of photosynthetic pigment, i.e. the chlorophyll content in plants (sajjad et al., 2014). Application of $\mathrm{GA}_{3} 50 \mathrm{ppm}$ increased the phenol content of leaves. Sardoei et al., (2014) found that $\mathrm{GA}_{3}$ resulted highest total phenolic content on Calendula officinalis. The reduction in phenol content with higher level reflected the dose-specificity of the crop (Sharaf-Eldin et al., 2007). Whereas, GA 3 @ $100 \mathrm{ppm}$ increased the leaf protein content, canopy temperature. 
Table.1 Effect of plant growth regulators on plant height, leaves per plant, leaf length and leaf width of Gladiolus cv. American Beauty

\begin{tabular}{|c|c|c|c|c|c|c|c|c|}
\hline Treatment & $\begin{array}{c}\text { Plant } \\
\text { Height } \\
\text { at } 21 \\
\text { DAP } \\
\text { (cm) }\end{array}$ & $\begin{array}{c}\text { Plant } \\
\text { Height } \\
\text { at } 63 \\
\text { DAP } \\
(\mathrm{cm})\end{array}$ & $\begin{array}{c}\text { Leaves } \\
\text { per } \\
\text { plant at } \\
21 \text { DAP }\end{array}$ & $\begin{array}{c}\text { Leaves } \\
\text { per } \\
\text { plant at } \\
63 \text { DAP }\end{array}$ & $\begin{array}{c}\text { Leaf } \\
\text { Length } \\
\text { at } 21 \\
\text { DAP } \\
(\mathrm{cm})\end{array}$ & $\begin{array}{c}\text { Leaf } \\
\text { Length } \\
\text { at } 63 \\
\text { DAP } \\
(\mathrm{cm})\end{array}$ & $\begin{array}{c}\text { Leaf } \\
\text { Width } \\
\text { at } 21 \\
\text { DAP } \\
\text { (cm) }\end{array}$ & $\begin{array}{c}\text { Leaf } \\
\text { Width at } \\
63 \text { DAP } \\
\text { (cm) }\end{array}$ \\
\hline $\mathbf{T}_{0}$ & 7.26 & 59.30 & 2.20 & 6.83 & 5.06 & 45.43 & 0.77 & 1.57 \\
\hline$T_{1}$ & 12.72 & 58.26 & 2.50 & 7.44 & 10.05 & 46.55 & 0.98 & 2.12 \\
\hline $\mathbf{T}_{2}$ & 10.26 & 56.06 & 2.39 & 6.17 & 5.46 & 44.88 & 0.90 & 1.99 \\
\hline $\mathbf{T}_{3}$ & 13.17 & 71.67 & 2.78 & 10.83 & 7.91 & 57.72 & 0.96 & 2.26 \\
\hline $\mathbf{T}_{4}$ & 8.52 & 58.96 & 2.50 & 6.86 & 7.49 & 48.81 & 0.78 & 1.75 \\
\hline $\mathbf{T}_{5}$ & 3.65 & 51.12 & 2.83 & 6.28 & 4.06 & 40.70 & 0.48 & 1.70 \\
\hline$T_{6}$ & 7.76 & 65.43 & 1.96 & 7.89 & 8.04 & 56.06 & 0.73 & 1.14 \\
\hline $\mathbf{T}_{7}$ & 10.42 & 55.92 & 2.94 & 6.17 & 5.41 & 39.81 & 0.95 & 1.82 \\
\hline $\mathbf{T}_{8}$ & 14.49 & 64.31 & 3.08 & 7.61 & 9.24 & 57.96 & 1.68 & 2.63 \\
\hline $\mathbf{T}_{9}$ & 9.16 & 75.67 & 2.08 & 11.61 & 6.51 & 52.00 & 0.72 & 1.87 \\
\hline S. $E_{m} \pm$ & 2.91 & 3.73 & 0.24 & 0.65 & 0.41 & 2.89 & 0.24 & 0.18 \\
\hline C.D at $5 \%$ & NS & 11.08 & 0.70 & 1.92 & 1.21 & 8.58 & NS & 0.54 \\
\hline C.V. & 51.83. & & & & & & 46.38 & \\
\hline
\end{tabular}

Table.2 Effect of plant growth regulators on reducing sugar, non-reducing sugar, protein content, Enzyme activity and phenol content of leaf in Gladiolus cv. American Beauty

\begin{tabular}{|c|c|c|c|c|c|}
\hline Treatment & $\begin{array}{l}\text { Reducing } \\
\text { Sugar content } \\
\text { of Leaf (mg/g } \\
\text { of fresh } \\
\text { weight) }\end{array}$ & $\begin{array}{c}\text { Non- } \\
\text { Reducing } \\
\text { sugar content } \\
\text { of Leaves } \\
\text { (mg/g of fresh } \\
\text { weight) }\end{array}$ & $\begin{array}{l}\text { Leaf protein } \\
\text { content }(\mathrm{mg} / \mathrm{g} \\
\text { of fresh } \\
\text { weight) }\end{array}$ & $\begin{array}{c}\text { Enzyme activity } \\
\text { of leaf } \\
(\Delta 490 \mathrm{~nm} / \mathrm{min} / \mathrm{g} \\
\text { fresh weight })\end{array}$ & $\begin{array}{c}\text { Leaf phenol } \\
\text { content } \\
\text { (mg/g of } \\
\text { fresh } \\
\text { weight) }\end{array}$ \\
\hline $\mathbf{T}_{0}$ & 4.163 & 0.39748 & 2.45 & 1.20 & 0.71 \\
\hline $\mathbf{T}_{1}$ & 4.173 & 0.39742 & 2.40 & 1.13 & 1.25 \\
\hline $\mathbf{T}_{2}$ & 4.173 & 0.39744 & 2.34 & 1.13 & 1.84 \\
\hline $\mathbf{T}_{3}$ & 4.180 & 0.39738 & 2.49 & 1.20 & 0.27 \\
\hline $\mathbf{T}_{4}$ & 4.230 & 0.39742 & 1.87 & 1.13 & 0.31 \\
\hline $\mathbf{T}_{5}$ & 4.217 & 0.39742 & 1.59 & 1.20 & 0.88 \\
\hline $\mathbf{T}_{6}$ & 4.210 & 0.39744 & 2.16 & 1.27 & 0.68 \\
\hline $\mathbf{T}_{7}$ & 4.207 & 0.39744 & 1.84 & 1.07 & 1.28 \\
\hline $\mathbf{T}_{8}$ & 4.196 & 0.39742 & 1.94 & 1.27 & 1.01 \\
\hline $\mathbf{T}_{9}$ & 4.190 & 0.39746 & 2.31 & 1.13 & 1.07 \\
\hline S. $\mathbf{E}_{\mathbf{m}} \pm$ & 0.01 & 0.0000296 & 0.11 & 0.03 & 0.15 \\
\hline C.D at $5 \%$ & 0.03 & NS & 0.32 & 0.1 & 0.44 \\
\hline C.V. & & 0.01 & & & \\
\hline
\end{tabular}


Fig.1 The effect of plant growth regulators on canopy temperature of Gladiolus

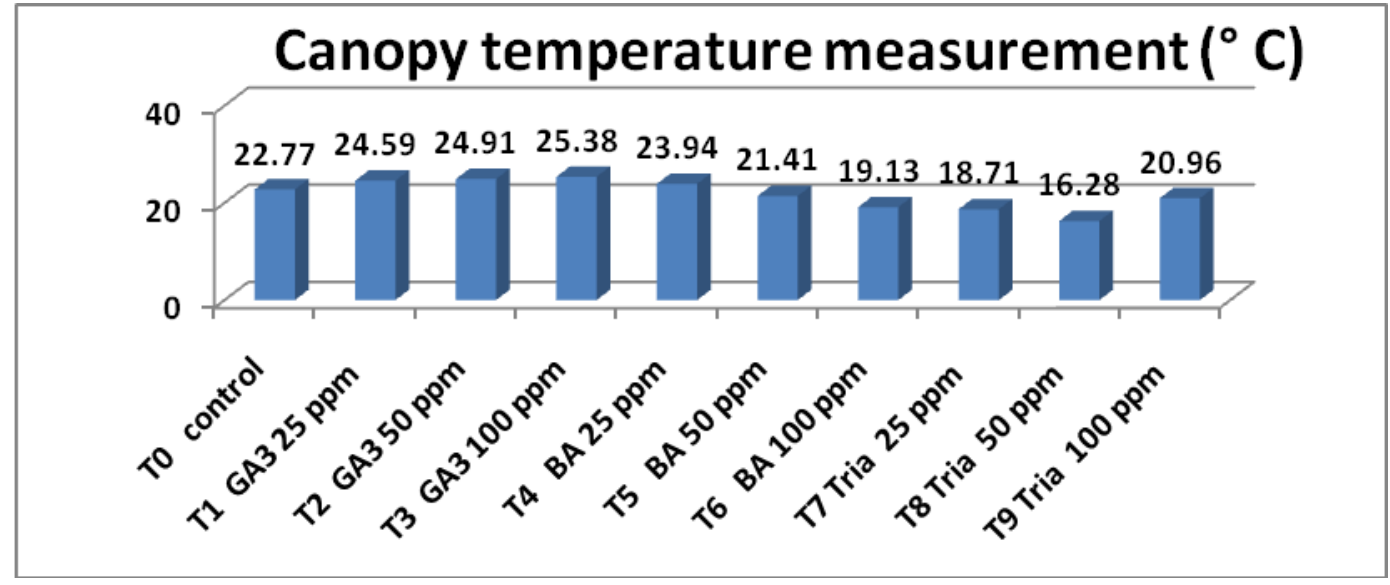

Fig.2 The effect of plant growth regulators on leaf chlorophyll estimation of Gladiolus

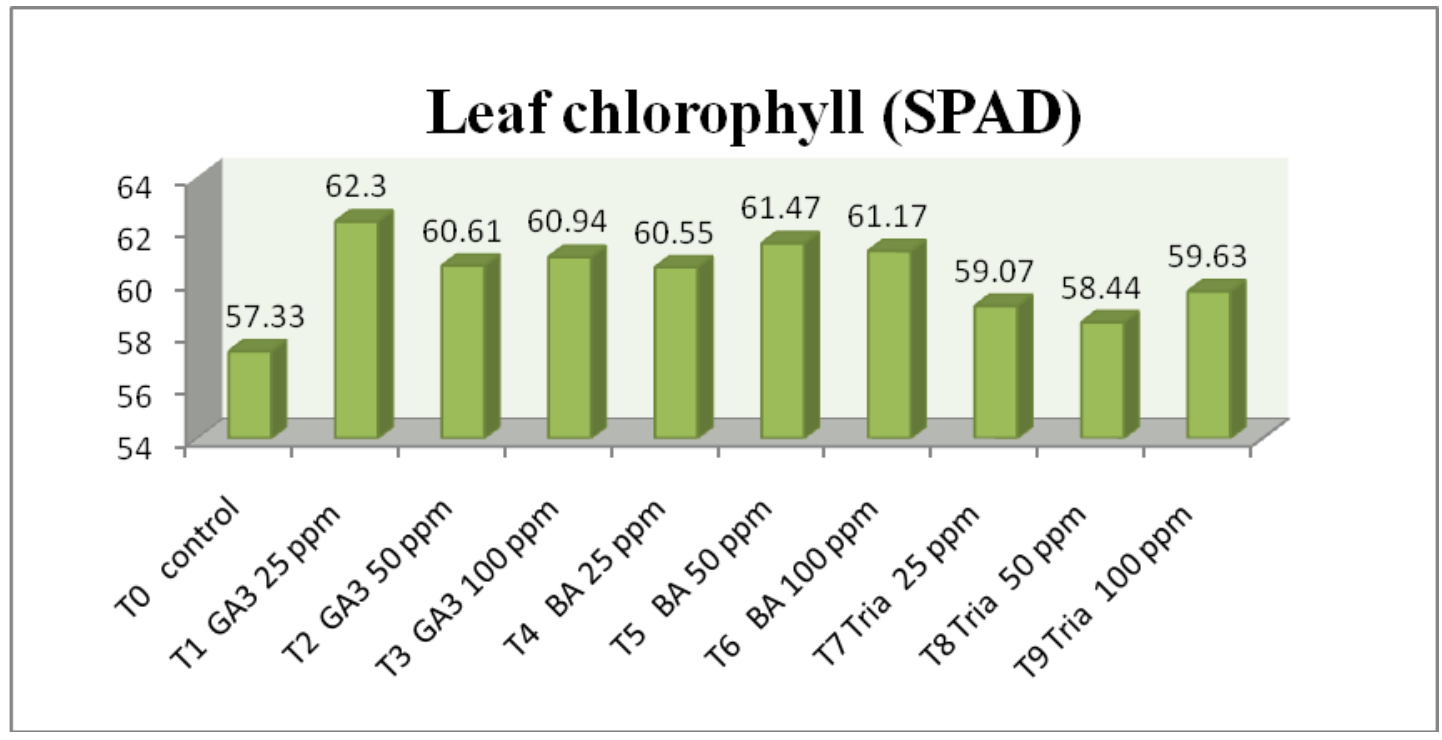

The findings were in agreement with the findings of Bhalla and Kumar (2008) and Dogra et al., (2012) in Gladiolus.

Exogenous application of BA 25ppm improved the reducing sugar content of leaf (4.230 $\mathrm{mg} / \mathrm{g}$ of fresh weight). BA delayed senescence of gladiolus spikes probably by retarding the rate of breakdown of synthesised protein and increasing the soluble sugar (Faraji and Basaki, 2014). Tricontanol is a growth promoter for several crop plants like ginger (Singh et al., 2012), hyacinth beans
(Naeem et al., 2009), tomato (Khan et al., 2009), mungbean (Reddy et al., 2002), rice (Pandey et al., 2001) etc. Exogenous application of Tricontanol improved the growth in plants might be due to the triggering effect on photosynthesis. Triacontanol increased the growth and quality of Chrysanthemum morifolium (Skoren et al., 1982). In the present experiment application of Triacontanol @ 50ppm improved initial plant height $(14.49 \mathrm{~cm})$, initial leaf production (3.08), initial and final leaf width $(1.68 \mathrm{~cm}$ and $2.63 \mathrm{~cm}$ respectively), leaf enzyme 
activity (1.27 $\Delta 490 \mathrm{~nm} / \mathrm{min} / \mathrm{g}$ fresh weight) and final leaf length $(57.96 \mathrm{~cm})$. The increase in plant height using Tricontanol and $\mathrm{GA}_{3}$ through increase in cell elongation in apical meristem resulting increased intermodal length (Sainath, 2009). Triacontanol 100ppm improved the final plant height $(75.67 \mathrm{~cm})$, final leaf production per plant (11.61). Triacontanol resulted better root development which is further helpful for utilization of nutrient as well as improved the photosynthetic activity in crops thereby developed better flowering, minimizing flower and fruit drop, improvement in nitrogen fixation, enzyme activities, free amino acids, reducing sugars and soluble protein in plants as observed by Ries (1991). Triacontanolmediated improvement in growth, yield, photosynthesis, protein synthesis, uptake of water and nutrients, nitrogen-fixation, enzymatic activities and contents of free amino acids, reducing sugars, soluble protein, and active constituents of essential oil were observed in various crop plants [Idrees et al., (2010); Naeem et al., (2011)]. It enhances the physiological efficiency of the cells and exploits the genetic potential of plant to a large extent. Actually, it increased free amino acids, reducing sugars, and soluble protein in rice and maize (Ries, 1991).

\section{References}

Amanullah, M. M., Sekar, S. and Vincent, S. (2010). Plant growth substance in crop production: A review. Asian Journal of plant Sciences. 9(4): 215-222.

Amanullah, M. M., Sekar, S. and Vincent, S. 2010. Plant growth substance in crop production: A review. Asian Journal of plant Sciences. 9(4): 215-222.

Anonymous. 2014. Area, production \& productivity of flowers in west Bengal. Directorate of Horticulture, Government of West Bengal.

Bhalla, R., and Kumar, A. 2008. Response of plant bio-regulators on dormancy breaking in gladiolus. Journal of Ornamental
Horticulture. 11 (1): 1-8.

Da Silva Vieira, M. S., De Souza, A.V., Santos, C. M. G. De Sousa Alves, L., Cerqueira, R. C., De Alencar Paes, R., De Souza, A. D. and De Sousa Fernandes, L. M. 2011. Stem diameter and height of chrysanthemum cv. Yokoono as affected by gibberellic acid. African Journal of Biotechnology. 10, 11943-11947.

Dogra, S., Pandey, R. K. and Bhat, D. J. 2012. Influence of gibberellic acid and plant geometry on growth, flowering and corm production in gladiolus (Gladiolus grandiflorus) under Jammu agro climate. International Journal of Pharma and Bio Sciences. 3(4): $1083-1090$.

Faraji, S., and Basaki, T. 2014. Effect of Indole-3Acedic Acid and Benzyl Adenine on Morphological and biochemical Properties of Gladiolus. Journal of current research in science.14 (5): 580-584.

Farhat, T., 2004. Plant characteristic and vase life of gladiolus flowers as influenced by the preharvest and NPK application and postharvest chemical treatment. M.Sc. (Hons). Thesis, Pir Mehr Ali Shah- Arid Agriculture University. Pp: 2.

Havale, V. B., Tawar, R. V., Hage, N.D., Kakad, G. J., Fathepurkar, S.C. and Sable, A.S. 2008. Effect of growth regulators and chemicals on growth and flowering of gladiolus. The Asian Journal of Horticulture. 3(1): 93-94.

Idrees, M., Khan, M. M. A., Aftab, T. and Naeem, M. 2010. Synergistic effects of gibberellic acid and Triacontanol on growth, physiology, enzyme activities and essential oil content of Coriandrum sativum L. The Asian Australasian Journal of Plant Science Biotechnology. 4, 24-29.

Janowska, B., and M. Jerzy. 2003. Effect of gibberellic acid on postharvest leaf longevity of Zantedeschia elliottiana. Journal of Fruit and Ornamental. Plant Research. 11, 69-76.

Khan, F. N., Rahman, M. M. and Hossain, M. M. 2013. Effect of Benzyladenine and Gibberellic Acid on Dormancy Breaking, Growth and Yield of Gladiolus Corms over Different Storage Periods. Journal ornamental and horticultural plants. 3(1): 
59-71.

Khan, M. M. A., Bhardwaj, G., Naeem, M., Moinuddin, Mohammad, F., Singh, M., Nasir, S. and Idrees, M. 2009. Response of tomato (Solanum lycopersicum L.) to application of potassium and Triacontanol. Acta Horticulture. 823, 199-208.

Lowry, O. H., Rosebrough, N. J., Farr, A. L. and Randall, R. J. 1951. Protein Measurement with the Folin Phenol Reagent. Journal of Biology and Chemistry. 193, 265-275.

Malik, E. P., and Singh, M. B. 1980. Plant Enzymology and Hittoenzymology (1st Edn.). Research Journal of Pharmaceutical, Biological and Chemical Science. Pp. 286.

Mandava, N. B., 1979. Natural products in plant growth regulation. In: NB Mandava, editor. Plant growth substances. ACS Symposium Series 111. Washington (DC): American Chemical Society. Pp. 137-213.

Marcos, R. D. S. V., Giuseppina, P. P. L., Angela, V. D. S., Paula, N. C., Caio, M. G. S., Leonardo, D. S. A. and Nelson, G. D. O. 2011. Effect of gibberellic acid on the quality of chrysanthemum (Dendranthema grandiflora L.) cv. Faroe. African Journal of Biotechnology. 10(71): 15933-15937.

Memon, N., 2009. Introduction of Establishing protocols for the propagation of gladiolus. Institute of Horticultural Sciences, University of Agriculture, Faisalabad, Pakistan. Pp. 1-191.

Mukhopadhyay, A., 2002. Gladiolus. M/s Vinayak Press, B-177/1, Okhla Industrial Area, Phase-1. New Delhi. Pp. 2.

Naeem, M., Khan, M. A., Moinuddin and Siddiqui, M. H. 2009. Triacontanol stimulates nitrogen-fixation, enzyme activities, photosynthesis, crop productivity and quality of hyacinth bean (Lablab purpureus L.). Scientia Horticulturae. 121, 389-396.

Naeem, M., Khan, M. M. A., Moinuddin, Idrees, M. and Aftab, T. 2011. Triacontanolmediated regulation of growth and other physiological attributes active constituents and yield of Mentha arvensis L. Plant Growth Regulation. 65, 195-206.

Nelson, N., 1944. A photometric adaptation of the Somogyi method for the determination of glucose. Journal of Biological Chemistry. 153, 375-380.

Pandey, S., Behura, D., Villano, R. and Naik, D. 2001. Drought risk, farmer's coping mechanisms and poverty: a study of the rainfed rice system in eastern India. In: Rice research for food security and poverty alleviation. (Eds.): S. Peng, B. Hardy IRRI, Los Banos, Philippines, Pp. 267-275.

Rani, P., and Singh, N. 2013. Impact of gibberellic acid pretreatment on growth and flowering of tuberose (Polianthes tuberosa L.) cv. Prajwal. Journal of Tropical Plant Physiology. 5, 33-41.

Reddy, B. O., Giridhar, P. and Ravishankar, G. A. 2002. The effect of Triacontanol on micropropagation of Capsicum frutescens and Decalepis hamiltonii W \& A. Plant Cell Tissue Organ Culture. 71, 253-8.

Reddy, P., Ninganur, B. T., Chetti, M. B. and Hiremath, S. M. (2009). Effect of growth retardants and nipping on chlorophyll content, nitrate reductase activity, seed protein content and yield in cowpea (Vigna unguiculata L.). Karnatak Journal of Agricultural Science. 22(2): 289-292.

Ries, S., 1991. Triacontanol and its second messenger 9-b-L (+)-adenosine as plant growth substances. Plant Physiology. 95, 986-989.

Sadasivam, S., and Manickam, A. 1996. Biochemical methods. 2nd Edn, New Age International Publishers. Pp. 107-109.

Sainath., 2009. Influence of spacing, fertilizer and growth regulators on growth, seed yield and quality in annual Chrysanthemum (Chrysanthemum coronsrium L.). Thesis: master of science (agriculture) in seed science and technology. Dept of seed science and technology, college of agriculture, Dharwad, univerdity of agricultural sciences, dharwad.

Sajid, M., Anjum, M. A. and Hussain, S. 2015. Foliar application of plant growth regulators affects growth, flowering, vase life and corm production of Gladiolus grandiflorus L. under calcareous soil. Bulgarian Journal of Agricultural Science. 21 (5): 982-989.

Sajjad, Y., Jaskani, M. J. and Qasim, M. 2014. 
Response of morphological and physiological growth attributes to foliar application of plant growth regulators in gladiolus 'white prosperity. Pakistan Journal of Agricultural Sciences. 51(1):123-129.

Sardoei, A. S., Shahadadi, F., Vakili, M. A, and Gholamshahi, S. 2014. Effects of gibberellic acid $\left(\mathrm{GA}_{3}\right)$ on phenolic compounds and antiradical activity of marigold (Calendula officinalis). International Journal of Biosciences. 4 (3): $1-8$.

Shankar, K., Singh, A. K. and Singh, H. K. 2011. Effect of plant growth regulators on spike yield and bulb production of tuberose (Polianthes tuberose Linn.) cv. Double. Plant Archives. 11, 169-171.

Sharaf-Eldin, M. A., Schnitzler Nitz, W. H. G., Razin, M. and El-Oksh II., 2007. The effect of gibberellic acid $\left(\mathrm{GA}_{3}\right)$ on some phenolic substances in globe artichoke (Cynara cardunculus var scolymus (L.) Fiori. Scientia Horticulturae. 111, 326329.

Singh, A. K., 2006. Flower crops cultivation and management. New India publishing Agency, Pritam Pura, New Delhi-110 088. pp.147-148.

Singh, M., Khan, M. M. A., Moinuddin and Naeem, M. 2012. Augmentation of nutraceuticals, productivity and quality of ginger (Zingiber officinale Rosc.) through Triacontanol application. Plant Biosystems. 146(1): 106-113.

Sinha, P., and Roy, S. K. 2002. Plant regeneration through In vitro cormel formation from callus culture of gladiolus primulinus Baker. Plant tissue culture. 12(2): 139145.

Skogen, D., Eriksen, A. B. and Nilsen, S. (1982). Effects of Triacontanol on production and quality of flowers of Chrysanthemum moriflium. Ramat. Scientia Horticulturae. $18,87-92$.

Somogyi, M. (1945). A new reagent for the determination of sugars. Journal of Biological Chemistry. Pp. 160-161.

Sudhakar, M., and Kumar, S. R. 2012. Effect of growth regulators on growth, flowering and corm production of gladiolus (Gladiolus grandiflorus 1.) cv. white friendship. Indian Journal of Plant Sciences. 1 (2-3):133-136.

Umrao, V. K., Singh, R. P. and Singh, A. R. 2007. Effect of gibberellic acid and growing media on vegetative and floral attributes of gladiolus. Indian Journal of Horticulture. 64, 73-76.

\section{How to cite this article:}

Priyaranjan Koley, Soumen Maitra and Indrajit Sarkar 2019. Studies on the Exogenous Application of Plant Growth Regulators on Morphological and Biochemical Changes in Gladiolus (Gladiolus grandiflorus 1.) Leaf. Int.J.Curr.Microbiol.App.Sci. 8(09): 1869-1877. doi: https://doi.org/10.20546/ijcmas.2019.809.216 